\title{
Acanthochelys macrocephala (Rhodin, Mittermeier, and McMorris 1984) - Big-Headed Pantanal Swamp Turtle, Pantanal Swamp Turtle
}

\author{
Anders G.J. Rhodin ${ }^{1}$, Sébastien Métrailler ${ }^{2}$, Thomas Vinke ${ }^{3}$, Sabine Vinke ${ }^{3}$, \\ Harald Artner $^{4}$, and Russell A. Mittermeier ${ }^{5}$ \\ ${ }^{1}$ Chelonian Research Foundation, \\ 168 Goodrich St., Lunenburg, Massachusetts01462 USA [RhodinCRF@aol.com]; \\ ${ }^{2}$ Chemin du Bosquet 6, CH-1967 Bramois, Switzerland [s.metrailler@bluewin.ch]; \\ ${ }^{3}$ Filadelfia 853,9300 Fernheim, Paraguay [s-t-vinke@gmx.de]; \\ ${ }^{4}$ Maria Ponsee 32, 3454 Reidling, Austria [dr.h.artner@aon.at]; \\ ${ }^{5}$ Conservation International, 2011 Crystal Drive, Suite 500, \\ Arlington, Virginia 22202 USA [r.mittermeier@conservation.org]
}

Summary. - The big-headed Pantanal swamp turtle, Acanthochelys macrocephala (Family Chelidae), is a medium-sized aquatic turtle (carapace length to $295 \mathrm{~mm}$ ), endemic to the Pantanal and Chaco ecoregions of Brazil, Bolivia, and northern Paraguay. It has a limited distribution in the upper Río Paraguai drainage and is apparently restricted to the swampy lowlands of the Pantanal and the arid plains of the northern Chaco. The species inhabits marshes, wetland areas, shallow bays and brackish lagoons (salinas), as well as opportunistically utilizing ephemeral waterbodies, including roadside drainage ditches and farm irrigation reservoirs and artificial ponds in pasturelands (tajamares). Population levels appear relatively robust at present and the species is not uncommon, but ongoing patterns of habitat loss in the Chaco, combined with climate change leading to increased aridity and threat to ephemeral water resources potentially threaten the species, and it is currently categorized as Near Threatened on the IUCN Red List.

Distribution. - Brazil, Bolivia, Paraguay. Distributed in the upper Río Paraguai drainage, in the Pantanal ecoregion encompassing parts of Mato Grosso and Mato Grosso do Sul in Brazil, eastern Bolivia, and northern Paraguay, and in the Chaco ecoregion of southern Bolivia and northern and central Paraguay.

Synonymy. - Platemys macrocephala Rhodin, Mittermeier, and McMorris 1984, Acanthochelys macrocephala, Phrynops chacoensis Fritz and Pauler 1992, Acanthochelys chacoensis, Mesoclemmys chacoensis.

SuBSPECIES. - None currently recognized.

Status. - IUCN 2009 Red List: Near Threatened (LR/nt) (assessed 1996, needs updating); CITES: Not Listed.

Taxonomy. - This species was described as Platemys macrocephala by Rhodin, Mittermeier, and McMorris (1984a) based on specimens from the Pantanal region of Brazil and Bolivia. The type locality is Caiçara, RioParaguai,
Mato Grosso, Brazil ( $\left.16^{\circ} 03^{\prime} \mathrm{S}, 57^{\circ} 43^{\prime} \mathrm{W}\right)$ and the holotype (Naturhistorisches Museum Wien 1293) was collected by Johann Natterer in 1826. The holotype was first identified as a Platemys radiolata by Siebenrock (1904), who cred-

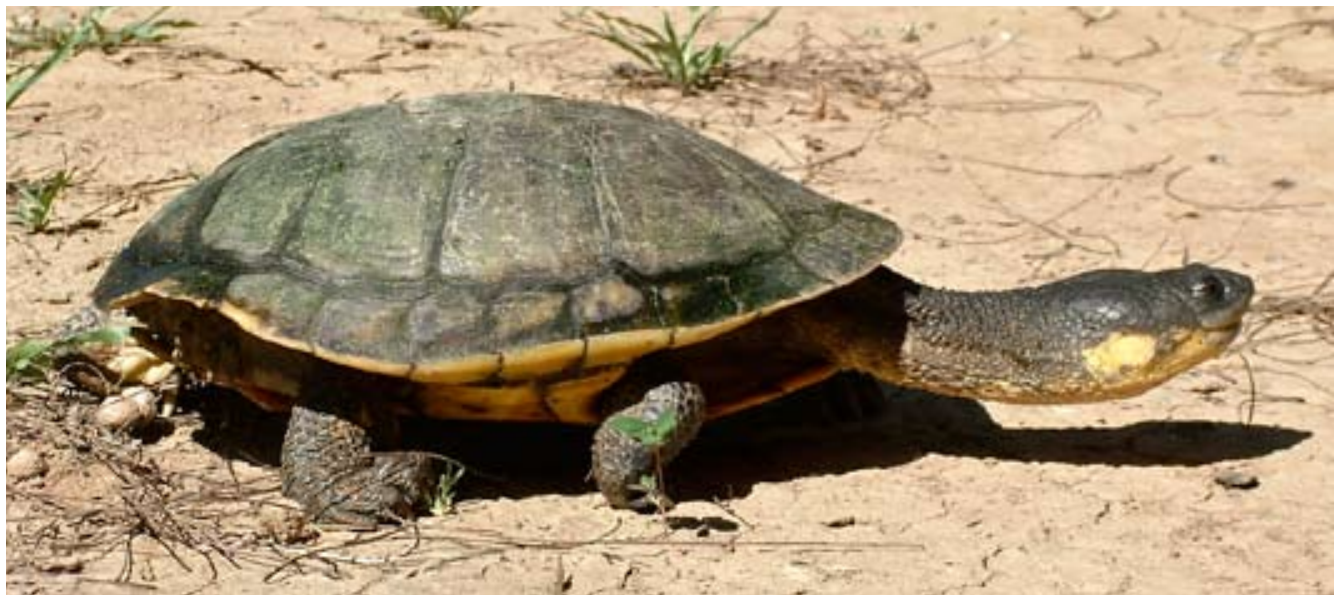

Figure 1. Acanthochelys macrocephala, adult female from nr. Filadelfia, Chaco, Paraguay. Photo by Thomas and Sabine Vinke. 

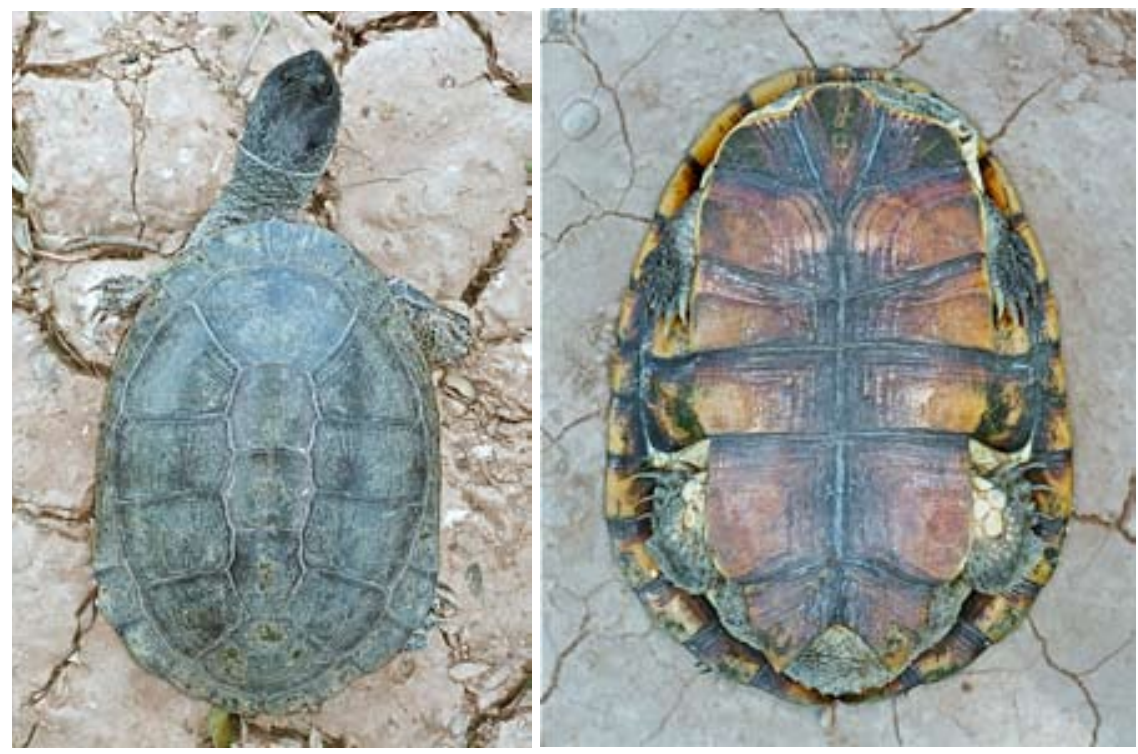

Figure 2. Acanthochelys macrocephala, adult female from the Paraguayan Chaco. Photos by Sébastien Métrailler.

ited Fitzinger with having earlier labeled the specimen as Phrynops schoepffii, but that name is a nomen nudum. The subsequently described species, Phrynops chacoensis Fritz and Pauler 1992, from the Chaco region of northern Paraguay, was later synonymized with A. macrocephala by the same authors (Fritz and Pauler 1999). A detailed morphologic and genetic analysis of whether or not the Pantanal and Chaco populations of this species are distinct lineages is needed.

In a karyological study, McBee et al. (1985) demonstrated that Platemys platycephala warranted monotypic status and that $P$.macrocephala, P.radiolata, P. spixii, and $P$. pallidipectoris represented a separate monophyletic lineage.

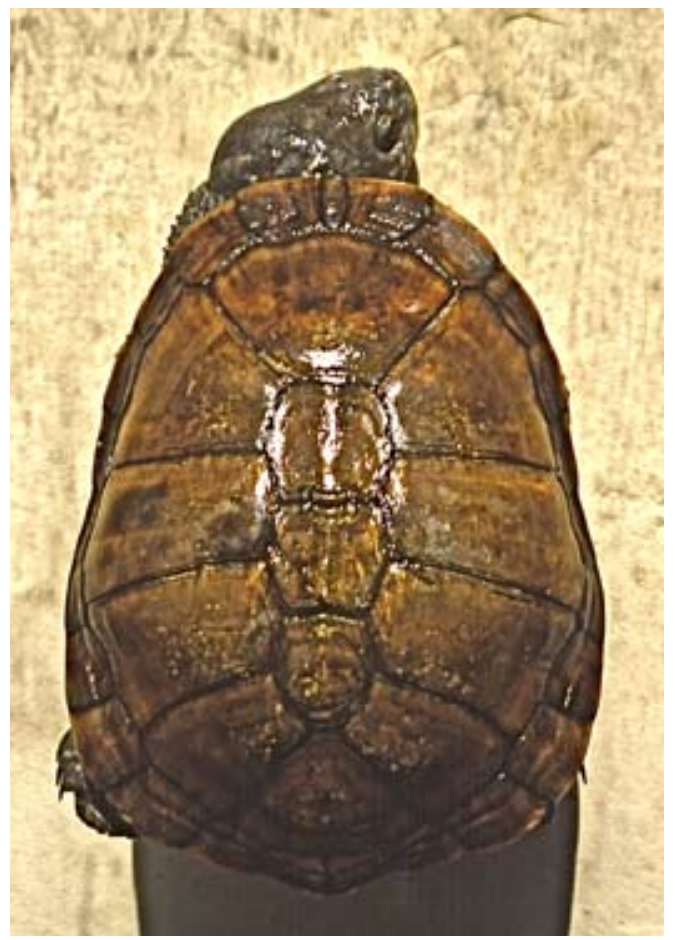

Figure 3. Acanthochelys macrocephala, adult female with megacephaly from Bolivia. Photo by Anders G.J. Rhodin.
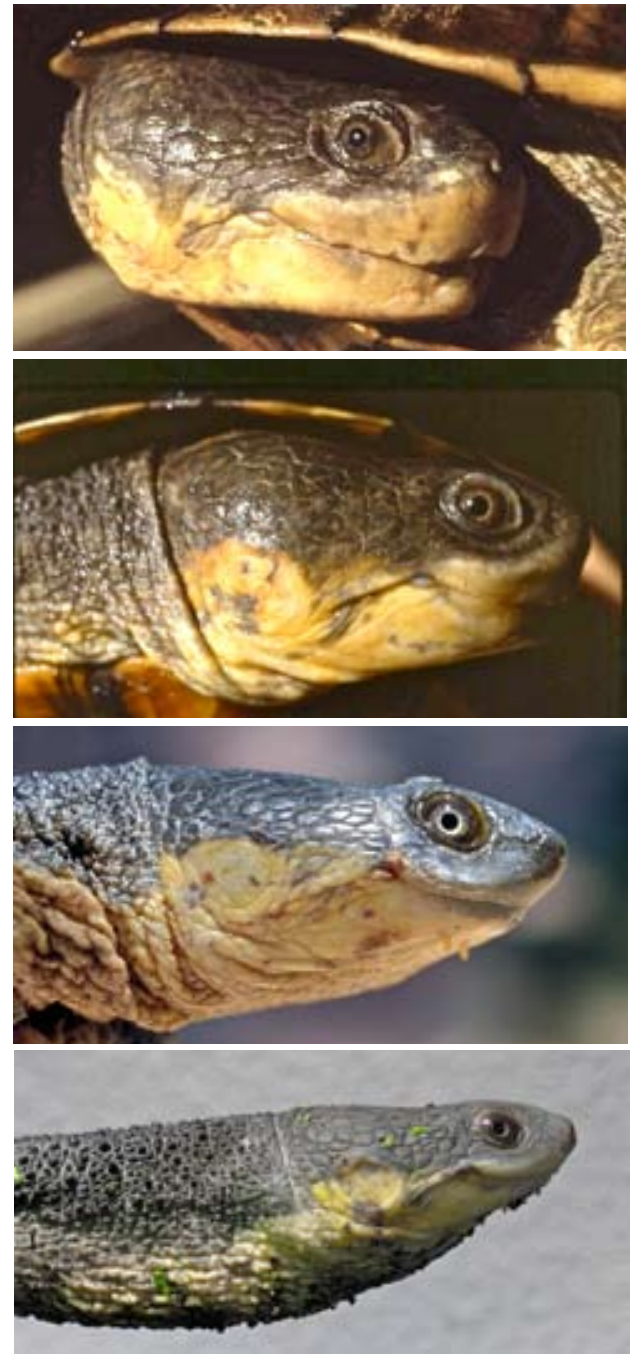

Figure 4. Acanthochelys macrocephala, (top two) adult females from Bolivia, photos by Anders G.J. Rhodin; (bottom two) adults from the Paraguayan Chaco, photos by Thomas and Sabine Vinke (above, sex unknown) and Sébastien Métrailler (below, female). Note the differences in head depth through the jaws 


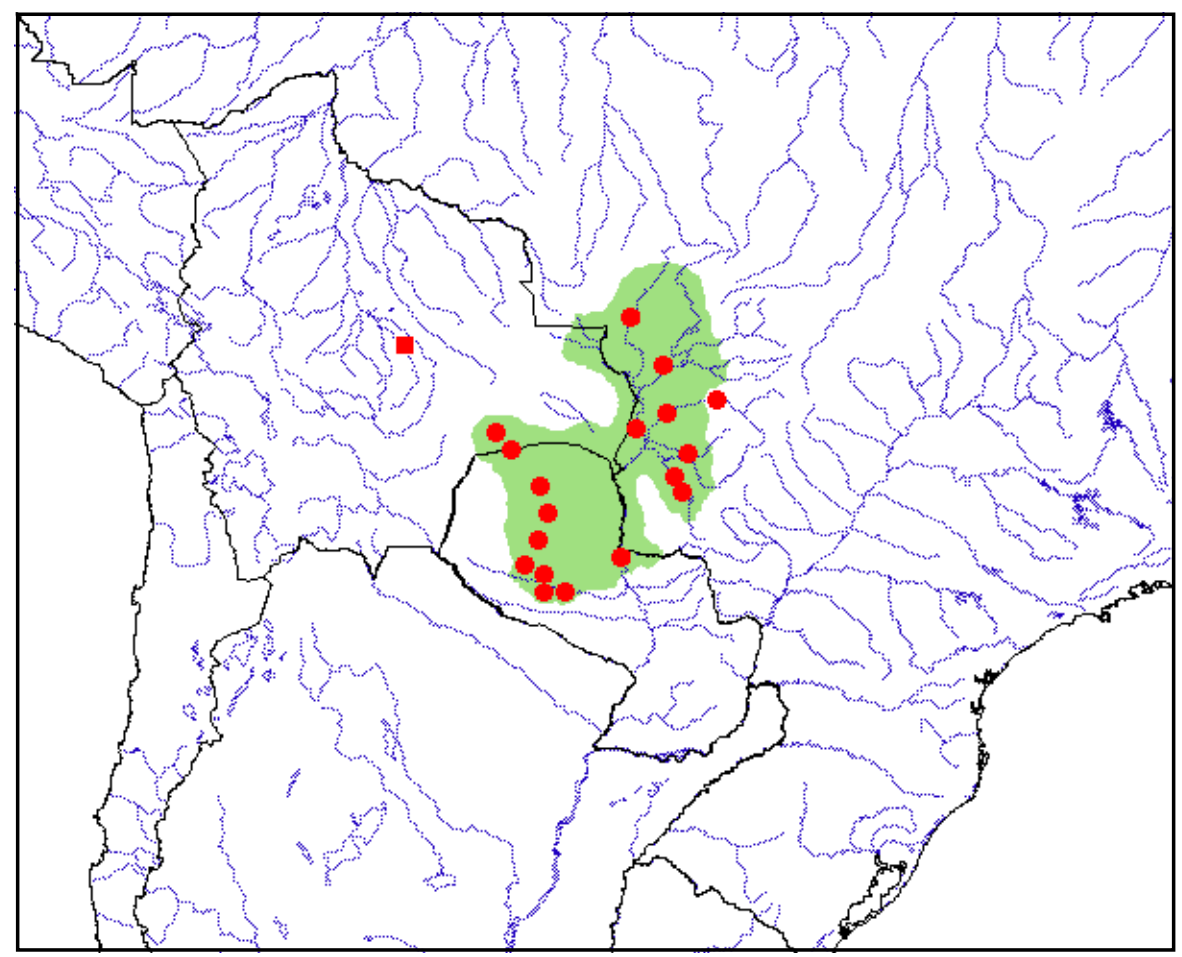

Figure 5. Distribution of Acanthochelys macrocephala in Brazil, Bolivia, and Paraguay in South America. Red points = museum and literature occurrence records based on Iverson (1992) plus more recent and authors' data; green shading = projected distribution based on GIS-defined hydrologic unit compartments (HUCs) constructed around verified localities and then adding HUCs that connect known point localities in the same watershed or physiographic region, and similar habitats and elevations as verified HUCs (Buhlmann et al., in press), and adjusted based on authors' data. Red square = trade specimen from the Río Mamoré probably not representing natural distribution; red point at eastern edge of distribution = skeletal specimen from Coxim probably from just outside the natural range.

Rhodin (1985) noted the availability of the generic name Acanthochelys Gray 1873 for this monophyletic group, and Iverson (1986) formalized this designation for the species as Acanthochelys macrocephala.

Morphologically and biochemically, A. macrocephala appears most closely related to A. radiolata (Rhodin et al. 1984b; Derr et al. 1987). Analysis of mitochondrial DNA confirms the monophyly of the four species of Acanthochelys, but demonstrates an apparently closer relationship of A. macrocephala with A. pallidipectoris and A. spixii

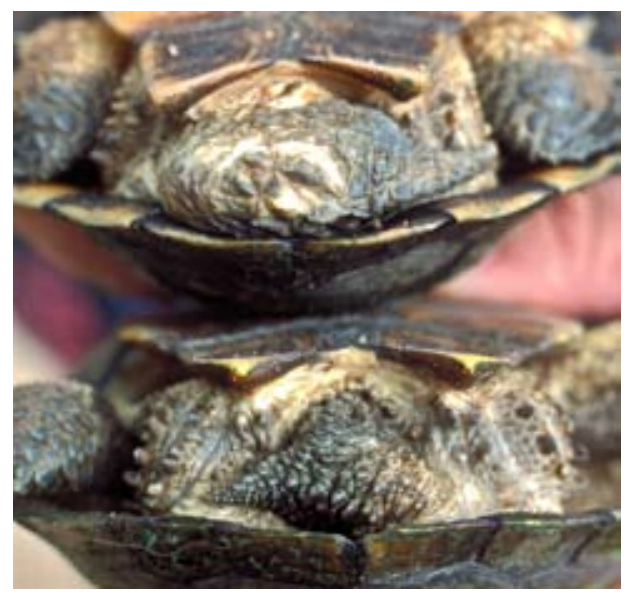

Figure 6. Acanthochelys macrocephala from Paraguayan Chaco, sexual dimorphism, male above, female below. Photo by Thomas and Sabine Vinke. than with A. radiolata (Huebinger et al. 2009, submitted). No phylogeographic studies have been done to determine whether Pantanal and Chaco populations of A. macrocephala are genetically monophyletic lineages or not, and
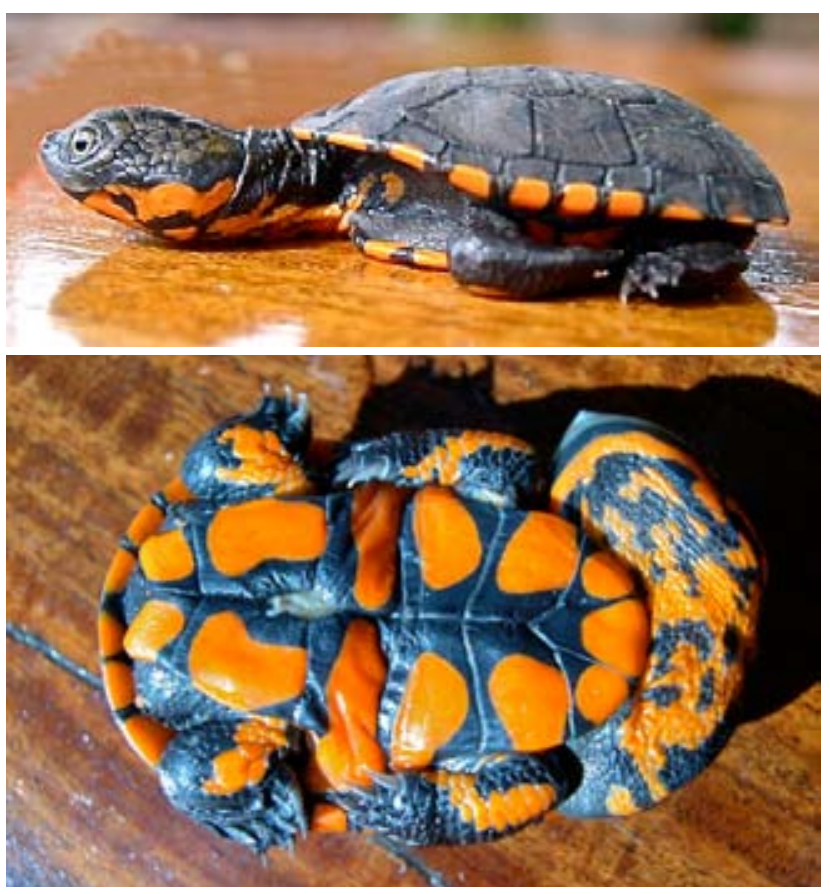

Figure 7. Acanthochelys macrocephala, hatchling from Miranda, Mato Grosso du Sul, Brazil. Photos by Fernanda Melo. 


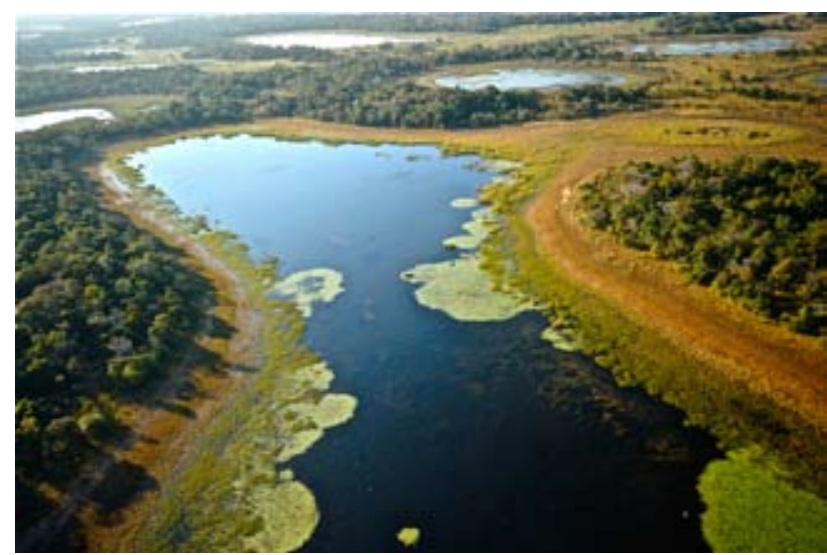

Figure 8. Typical Acanthochelys macrocephala habitat in the Brazilian Pantanal: salinas at Fazenda Rio Negro RPPN, Mato Grosso do Sul. Photo by Russell A. Mittermeier.

no subspecies or geographic variation has been described or documented. General reviews of the species have been published by Rhodin et al. (1990) and Rueda-Almonacid et al. (2007).

Description. - Acanthochelys macrocephala is a broad-headed medium-sized sidenecked turtle with carapace length (CL) up to $295 \mathrm{~mm}$, and the largest of the four species in its genus. There is prominent female-biased sexual dimorphism, with maximum recorded female CL of 295 $\mathrm{mm}$ and $235 \mathrm{~mm}$ for males (Cintra and Yamashita 1989). The light to dark brown carapace is broadly oval to moderately elongate (CL averages 1.42 times carapace width), and deep (CL averages 2.60 times depth in females; 2.81 times in males) with a very shallow dorsal groove present only in older animals extending along the second to fourth vertebrals. The carapace is highest just behind the center and broadest at the level of the anterior portion of the eighth marginals. A nuchal scute is present. The first and fifth vertebrals are very broad; the second through fourth may be slightly longer than wide. The carapacial rim is smooth; the first two marginals and the eighth to tenth are slightly expanded but not flared, while the third to seventh marginals are slightly upturned.

The broad plastron and the bridge are yellow with some dark pigment (which fades with age) extending along the seams (sometimes covering most of the adjacent scute, but usually not the areola). The broadly truncate or oval forelobe is broader than the hindlobe, which contains a deep posterior notch. The intergular scute is approximately half as large as the length of the forelobe, and is the longest scute on the plastron. The pectoral scute seam contact is usually the shortest.

The head is extremely broad (tympanic head width in adults averages $22.8 \%$ of CL, and older females may have massive megacephalic head widths of up to $27 \%$ of CL). In comparison, A.radiolata has tympanic head width averaging only $18.1 \%$ of CL. The head is dark gray-brown dorsally and yellow or cream ventrally; the area of demarcation is indistinct. The tympanum and posterior portion of the lower jaw are yellow with a few ventral gray blotches and a few

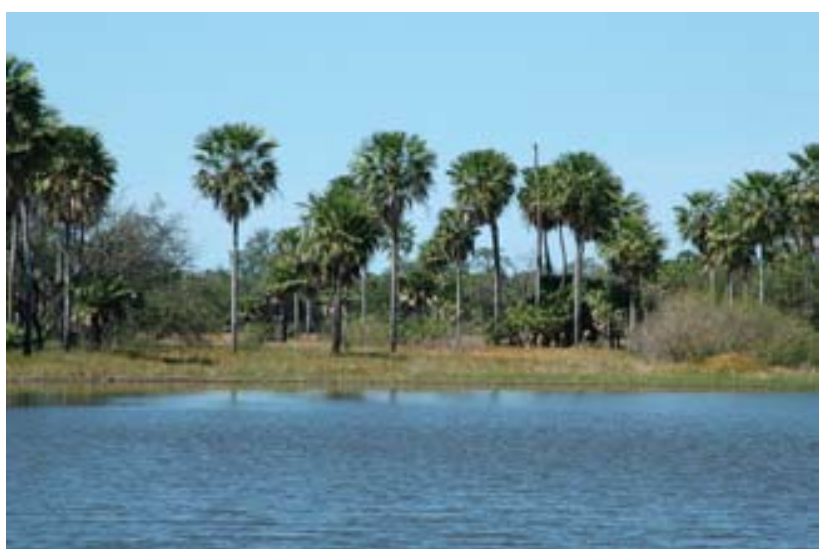

Figure 9. Typical Acanthochelys macrocephala habitat in the Paraguayan Chaco: natural shallow-water marshes. Photo by Thomas and Sabine Vinke.

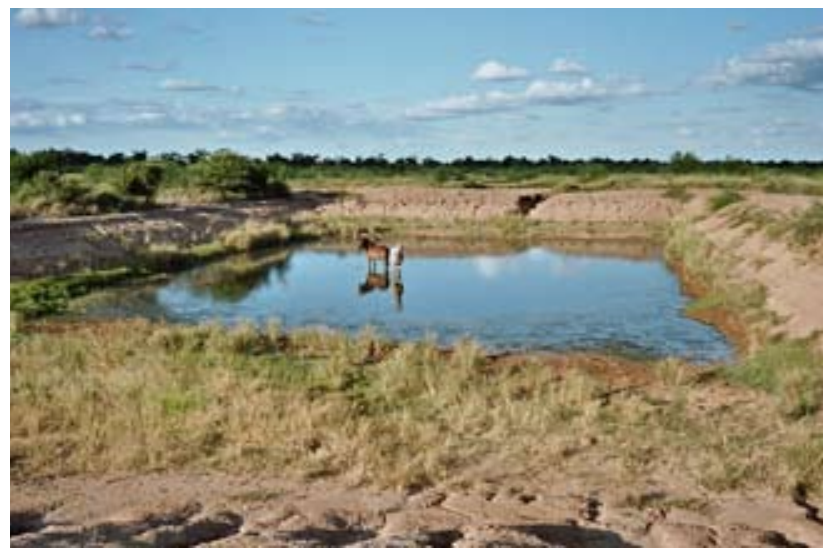

Figure 10. Typical Acanthochelys macrocephala habitat in the Paraguayan Chaco: artificial tajamares in pastureland. Photo by Sébastien Métrailler.

scattered orange spots along the area of demarcation. The anterior portions of the jaws are light grayish-yellow. The iris is brownish-tan to silvery gray without a black horizontal bar. The dorsal surface of the head is covered with relatively large distinct shields, not deeply sculpted. Two very small chin barbels are present.

The head width and depth through the jaws appears to vary somewhat between Pantanal and Chaco animals, with the former tending to have thicker, more robust jaws, and the latter having thinner, less robust jaws. Whether these apparent differences are diet-related or of taxonomic relevance is not known.

The neck is grayish-brown dorsally, yellow ventrally, and has a few scattered small blunt conical tubercles on the dorsal surface. The limbs are gray on the dorsal surface, yellowish below, often with small orange blotches along the interface. They are covered with large scales and have webbed toes. There are five claws on the forelimbs, four on the hindlimbs. A large pre-tibial flap of flattened raised scales occurs on the lateral surface of each lower leg. There are moderately enlarged conical ischial tubercles.

Hatchlings have been described by Cintra and Yamashita (1989), Artner (2007), and Ferronato and Molina (2009). 
Hatchlings have large heads and are very colorful ventrally, with large yellow or orange plastral markings. Hatchlings on average have a CL of $34.0 \mathrm{~mm}$ and mass of $8.0 \mathrm{~g}$, but have been recorded with a CL of up to $40 \mathrm{~mm}$. When hatching, they are folded transversely due to the roundish form of their eggs. The carapace and dorsal head are dark brown or gray with numerous small irregular black spots. The dorsal marginal scutes all have a single yellowish or orange triangle-shaped figure on their outer rims. The lateral head, including the tympanum and below, plus the chin and throat, are bright yellow or orange with irregular black vermiculations and spots. The plastron has an extensive bright yellow or orange pattern with a narrower black pattern following the seam contacts.

The shell has no neural bones. The cervical vertebrae have a central articulation pattern of $(2(3(4(5) 6) 7(8)$. The skull is deep, broad, and robust. The parietal roof is narrow due to broad temporal emargination, and there is a narrow parieto-squamosal temporal arch. The internal choanae are small, and the maxillary triturating surface extremely robust and wide.

Distribution. - Acanthochelys macrocephala is distributed in the upper Río Paraguai drainage, including the lowland swamps of the Pantanal ecoregion of the western parts of Mato Grosso and Mato Grosso do Sul of Brazil, the eastern parts of Santa Cruz in Bolivia, and the northern parts of Paraguay; as well as in the northeastern Chaco ecoregion of the southern parts of Santa Cruz in Bolivia and the drier plains of northern and central Paraguay.

Since the original description by Rhodin et al. (1984a), several new localities and range extensions for the species have been reported (Buskirk 1988; Cintra and Yamashita 1989; Vinke and Vinke 2001, 2008; Ziegler et al. 2002; Métrailler 2003, 2006; Dosapey and Montaño 2004; Mauro et al. 2004; Kinas et al. 2005; Gustafson 2006; Artner 2007; Ferronato and Molina 2009). Avila et al. (2006) also reported a range extension for the species, but then retracted it due to a misidentification of the specimen (actually a Mesoclemmys vanderhaegei). The species appears to be absent from the drier upland Cerrado habitat surrounding the lowland swampy Pantanal in Brazil (Ferronato and Molina 2009).

It is possible that $A$. macrocephala might not be native in some portions of the central (drier) Chaco of Paraguay, having possibly migrated into these regions as a result of the landscape being altered since the 1930s by extensive cattle farming, pastureland development, and creation of artificial freshwater habitats. The species makes frequent use of the extensive roadside drainage ditches and artificial ponds in these developed areas (Vinke and Vinke 2008).

Habitat and Ecology. - This species inhabits marshes, wetland areas, shallow bays and brackish lagoons (locally known as salinas in Brazil). Mauro et al. (2004) and Mittermeier et al. (2005) noted that A. macrocephala prefers brackish lagoons in the Nhecolândia region of the Pantanal, many of which dry up in the dry season (July-September). Artner (2007) observed animals only in ephemeral waterbodies, including roadside drainage ditches, farm irrigation reservoirs and artificial ponds in pastureland (locally known as tajamares in Paraguay), and noted an apparent preference for large shallow water bodies. In the Chaco, Vinke and Vinke (2008) observed them using shallow ephemeral waterbodies just for migration, and noted their preference for deeper artificial ponds and brackish lagoons that received water from high groundwater levels.

The species is opportunistic in feeding, including snails, tadpoles, and small aquatic insects (Métrailler 2003). Artner (2007) suggested that the diet is mainly snails and aquatic insects. Vinke and Vinke (2008) observed the species preying on small fish and frogs. Many species that serve as a food source for A. macrocephala in the Chaco, such as fish, aquatic insects, and tadpoles, are adapted to survive both in freshwater and brackish habitats. A waterbody with a permanent concentration of $4000 \mathrm{ppm}$ salt showed no notable constraint in diversity (Vinke and Vinke, unpubl. data).

Annual aestivation by A.macrocephala during the cooler and dry period in the Chaco seems to be obligatory, independent of availability of water. Animals leave the water at the end of the rainy season (March-April in the Chaco) and aestivate terrestrially until the first heavy rains the following spring (October-December in the Chaco) (Vinke and Vinke 2008 , in press). In southern Bolivia, aestivation appears to be facultative if water is available (Dosapey and Montaño 2004).

The reproductive period appears to be slightly different in the two ecoregions in which the species occurs, probably related to differences in the seasonality of the wet and dry seasons. In the Paraguayan Chaco, Vinke and Vinke (2001) observed mating in the wild in February in brackish lagoons, and all females examined by Métrailler (2003) and Artner (2007) in February were gravid, with a single egg measured at $27.5 \times 26 \mathrm{~mm}$. In the Brazilian Pantanal, Cintra and Yamashita (1989) recorded nesting in the wild in April-May, with clutch sizes of 4 and 8, and egg diameters of approximately $28.6-31.8 \mathrm{~mm}$ in length and $26.3-30.8 \mathrm{~mm}$ in width and mass of $12.2-19.3 \mathrm{~g}$ each. A single hatchling from these eggs measured $38 \mathrm{~mm} \mathrm{CL}$ and had a mass of $10 \mathrm{~g}$. Wild hatchlings in the Paraguayan Chaco are said to emerge around December (Artner 2007). Ferronato and Molina (2009) recorded wild hatchlings of ca. $40 \mathrm{~mm}$ CL from the Brazilian Pantanal in January. Artner (2007) recorded that Paraguayan Chaco animals laid clutches of 7-9 eggs in captivity that required diapause for successful incubation (see Captive Husbandry), and hatchlings measured about $34 \mathrm{~mm} \mathrm{CL}$ with a mass of about $8 \mathrm{~g}$.

Sexual dimorphism in the wild in the Paraguayan Chaco became noticeable at a CL of $141 \mathrm{~mm}$ for males and $162 \mathrm{~mm}$ for females (Métrailler 2006). In captivity, animals began to display sexual dimorphism at about $120 \mathrm{~mm} \mathrm{CL}$ (Artner 2007).

Sex ratio in a natural population in the Chaco of southern Bolivia was female-biased, with 0.67 males:females $(n=36)$, with maximum female CL of $279 \mathrm{~mm}$ and maximum male CL 
of $225 \mathrm{~mm}$ (Dosapey and Montaño 2004). A natural population in the Alto Chaco of Paraguay was also female-biased (0.4 males:females, $\mathrm{n}=21$ adults) (Métrailler 2006).

For a primarily tropical species, A.macrocephala shows great adaptability to extreme temperatures, especially in the dry Chaco region of northern Paraguay. Temperature data recorded over an 18-month period at two study sites for the species in this region showed a maximum air temperature of $40.2^{\circ} \mathrm{C}$ in October and a minimum $2.3^{\circ} \mathrm{C}$ in July, and surface water temperatures between 30 and $34^{\circ} \mathrm{C}$ in March (Métrailler 2006). Large variations could occur in a single day (e.g., a range of 11 to $34.5^{\circ} \mathrm{C}$ on 28 September 2005), and the largest variations were recorded during July, August, and September. Temperatures in the species' general habitat in the northern Paraguayan Chaco vary even more broadly, from -5 to $48^{\circ} \mathrm{C}$ (Vinke and Vinke, unpubl. data).

In the Paraguayan Chaco,A.macrocephala often occurs in microsympatry with the scorpion mud turtle, Kinosternon scorpioides scorpioides, which is much more abundant and more easily trapped and occurs in a wider variety of habitats (Artner 2007). It also occurs partially sympatrically with $A$. pallidipectoris, but that species is much rarer and infrequently encountered. It is possible that $A$. macrocephala migrating along ephemeral waterbodies in the Chaco may be displacing native A. pallidipectoris from the few habits where it occurs, but this is only an impression that needs further study (Vinke and Vinke 2008; pers. obs.). In the Pantanal, A. macrocephala occurs sympatrically with Phrynops geoffroanus (Mittermeier, pers. obs.).

Population Status. - No specific data available. However, studies by Dosapey and Montaño (2004) in pristine habitat in the Kaa-Iya del Gran Chaco National Park in southern Santa Cruz, Bolivia, found A. macrocephala present in nearly all aquatic habitats surveyed. Cintra and Yamashita (1989), Vinke and Vinke (2001,2008), and Artner (2007) also found the species to be relatively common and abundant in the habitats they surveyed.

Threats to Survival. - Both the Pantanal and the Chaco are considered among the most important wilderness ecoregions in the world (Mittermeier et al. 2002), and although both regions remain largely intact, as of earlier in this decade overall habitat loss was already estimated at $30 \%$ for the Chaco and 20\% for the Pantanal (Mittermeier et al. 2002). Agricultural and ranching development, especially extensive cattle grazing, is responsible for most of the ongoing habitat loss in the Chaco. Habitat loss is much less of a current concern in the Pantanal.

Although cattle ranching in the Chaco is degrading wilderness habitat, A. macrocephala seems to be adapting to the altered landscape by opportunistically utilizing artificial cattle ponds and road-side ditches (Vinke and Vinke 2001, 2008; Artner 2007). However, as global climate change causes increasing drought and aridity in the Chaco region, these and other ephemeral aquatic resources are becoming increasingly threatened, and the last few years have experienced more severe droughts than usual (Vinke and Vinke, pers. obs.). As a result, A. macrocephala may become increasingly threatened.
There appear to be very low trade levels for this species and apparently no legal trade.Provenance of trade specimens is currently apparently exclusively from Paraguay, destined for the international pet trade to USA, Europe, and Japan. Some previous pet trade emanated from Bolivia (Rhodin et al. 1984a). There is probably little or no trade from Brazil because of restrictive laws. The species is probably not currently traded from Bolivia because of marginal occurrence and relatively inaccessible habitat. Commerce in Paraguay has been declining since about 2005 , following more restrictive national legislation.

Conservation Measures Taken. - This species occurs in several protected areas, including the Pantanal Matogrossense National Park in Mato Grosso in Brazil, the Kaa-Iya del Gran Chaco National Park in Bolivia (Dosapey and Montaño 2004), and the Defensores del Chaco National Park in Paraguay (Vinke and Vinke, unpubl. data). In Brazil, federally protected areas account for only a very low percentage of protected habitat, with state and privately-controlled areas (Reservas Particulares do Patrimônio Natural; RPPN) increasing in importance (Mittermeier et al. 2005). For example, A. macrocephala occurs in the Fazenda Rio Negro RPPN near Aquidauana in southern Mato Grosso do Sul, a large privately-protected area owned by Conservaçaõ Internacional (CI-Brasil). This RPPN has joined forces with other similar reserves and a state park to create the Serra de Maracajú - Rio Negro Biodiversity Corridor, a 100,000 ha protected area (Mittermeier et al. 2005).

The species is currently categorized as Near Threatened on the 2009 IUCN Red List (www.iucnredlist.org), but that assessment was from 1996 and needs updating. A draft Red List re-assessment (Métrailler, Rhodin, and Vinke, unpubl. data) continues to categorize the species as Near Threatened, based primarily on actual and projected habitat loss in the Pantanal and Chaco, and climate-related drought threatening ephemeral water resources in the Chaco.

Conservation Measures Proposed. - No specific measures are recommended at this time, but research into population numbers and trends, and status of habitat should be undertaken and continued on an ongoing basis. Basic natural history, demographic, and ecological studies are also needed. Morphologic and phylogeographic genetic studies to determine whether or not Pantanal and Chaco populations are genetically distinct lineages would be very useful.

Captive Husbandry. - Captive care and breeding have been described by Artner (2007). Mating begins with the male placing himself in front of the female and displaying vertical head-bobbing. Nesting in captivity in Europe starts in early December as females increase their basking frequency and begin to inspect the nesting areas of their facilities during evening and night hours. Nesting takes place in the late evening hours and lasts two to three hours but is always finished before midnight. The nesting site is always in the vicinity of the area warmed by spotlights during the daytime. The nesting chambers are dug only by the hind legs, and are about $10 \mathrm{~cm}$ deep. After egg deposition, the female covers the nest using as much of the previously 
excavated material as possible. Clutches comprise between 7 and 9 eggs and are deposited between late December and late February.

Fertile eggs always stop developing if incubated at constant temperatures above $24^{\circ} \mathrm{C}$, because a natural diapause occurs even in captivity. This diapause almost never ceases without major changes in incubation techniques. A chill period of 3 months at $17^{\circ} \mathrm{C}$ or one month at $17^{\circ} \mathrm{C}$ with at least one week at $4^{\circ} \mathrm{C}$ immediately after the clutch was deposited has proven effective in breaking the diapause in most eggs. Normal embryonic development resumed when the eggs were again incubated at $29.5^{\circ} \mathrm{C}$ with air humidity levels around 70\%. After an incubation period of 96 to 117 days (excluding the chill period) or ca. 126 to 207 days (including a diapause chill period of 1-3 months), the eggs had to be opened as otherwise the embryos would die. Possibly, increased humidity indicating the first heavy rainfalls of the rainy season are necessary to induce natural hatching, but this needs verification.

Current Research. - We are unaware of any current work on this species.

Acknowledgments. - We thank Richard Vogt, John Iverson, and Ray Saumure for review comments, Bruno Ferronato and Paula Rylands for help obtaining photos, Fabio Scarano for information on protected areas, and Fernanda Melo for her photos of hatchlings.

\section{LITERATURE CITED}

ARTNER,H. 2007. Observations in the natural habitat in Paraguay and their implications for the first successful breeding of the Pantanal swamp turtle Acanthochelys macrocephala (Rhodin, Mittermeier, and McMorris, 1984). Emys 14(3):4-25.

Avila, R.W., Souza, F.L., Landgref-Filho, P., And CAmpos, A.L.C. 2006. Reptilia, Chelidae, Acanthochelys macrocephala: distribution, habitat, and geographical distribution map. Check List 2(2):35-37. [Erratum: = Mesoclemmys vanderhaegei . Published online].

Buhlmann, K.A., Akre, T.S., Iverson, J.B., Karapatakis, D., MitTERMEIER, R.A., GEORGES, A., RHODIN, A.G.J., vAN DiJK, P.P., AND GiBBONS, J.W.In press.A global analysis of tortoise and freshwater turtle distributions withidentification of priority conservation areas. Chelonian Conservation and Biology 8(2): in press.

BuSKIRK, J.R. 1988. New locality records in Argentina and Paraguay for chelid turtles, Platemys pallidipectoris (Freiberg) and Platemys macrocephala (Rhodin et al.). Herpetological Review 19(4):74-75.

Cintra, R. And Yamashita, C. 1989. Notes on the nesting ecology of Platemys macrocephala in the Brazilian Pantanal. Herpetological Review 20(3):65-66.

Derr, J.N., Bickham, J.W., Greenbaum, I.F., Rhodin, A.G.J., and MitTermeIER,R.A.1987. Biochemical systematics and evolution in the South American turtle genus Platemys (Pleurodira: Chelidae). Copeia 1987(2):370-375.

Dosapey, T. and Montaño, R.R. 2004. Estructura de la población y telemetría de Acanthochelys macrocephala (Testudines, Chelidae) en los humedales del sureste del Chaco de Santa Cruz, Bolivia. In: Bodmer, R.E.(Ed.). Memorias: Manejo de Fauna silvestre en Amazonia y Latinoamérica. Iquitos: Universidad Nacional de la
Amazonia Peruana, pp. 166-171.

Ferronato, B. De O. And Molina,F. DE B. 2009. Reptilia, Testudines, Chelidae, Acanthochelys macrocephala: distribution extension, geographic distribution map, and hatchling morphology. Check List 5(3):717-722.

Fritz, U. ANd PaUler, I. 1992. Phrynops chacoensis spec. nov. (Reptilia, Chelidae), eine neue Krötenkopfschildkröte.Mitteilung des Zoologischen Museums Berlin 68(2):299-307.

Fritz, U. ANd PaUler, I. 1999. Phrynops chacoensis Fritz \& Pauler, 1992, ein Juniorsynonym von Platemys macrocephala Rhodin, Mittermeier \& McMorris, 1984. Salamandra 35(1):53-56.

GRAY, J.E. 1873. Observations on chelonians, with descriptions of new genera and species. Annals and Magazine of Natural History (4)11:289-308.

Gustafson, A.W. 2006. Nouvelle localite pour Acanthochelys macrocephala (Rhodin, Mittermeier \& McMorris, 1984) au Paraguay. Manouria 9(33): 24-25.

Huebinger, R.M., Bickham, J.W., Rhodin, A.G.J., AND MitTermeier, R.A. Submitted. Molecular systematics of the South American chelid turtles of the genera Platemys and Acanthochelys. Chelonian Conservation and Biology, submitted.

IvERSON,J.B.1986.AChecklist with Distribution Maps of the Turtles of the World. Richmond, IN: Privately printed, $283 \mathrm{pp}$.

IvERSON, J.B. 1992. A Revised Checklist with Distribution Maps of the Turtles of the World. Richmond, Indiana: Privately printed, $363 \mathrm{pp}$.

KinAS, M.A., MAURo, R.A., AND SouZA, F.L. 2005. Geographic Distribution. Acanthochelys macrocephala. Herpetological Review 36(3):335.

Mauro, R.A., Kinas, M.A., AND SouzA, F.L. 2004. Acanthochelys macrocephala (Pantanal Swamp Turtle). Habitat. Herpetological Review 35:263.

McBee, K., Bickham, J.W., Rhodin, A.G.J., And Mittermeier, R.A. 1985. Karyotypic variation in the genus Platemys (Testudines: Pleurodira). Copeia 1985(2):445-449.

MÉTRAILler, S. 2003. Note sur l'écologie d'Acanthochelys macrocephala (Rhodin, Mittermeier \& McMorris, 1984) au Paraguay (Reptilia: Chelidae). Revue Suisse de Zoologie 110(3):483-490.

Métrailler, S. 2006. Ecologie de la Platémyde à grosse tête (Acanthochelys macrocephala) au Paraguay. Manouria 9(33):26-32.

Mittermeier, R.A., Mittermeier, C.G., Pilgrim, J., Fonseca, G., Konstant, W.R., AND BROOKs, T. 2002. Wilderness: Earth's Last Wild Places. Mexico: CEMEX, 576 pp.

Mittermeier, R.A., Harris, M.B., Mittermeier, C.G., Silva, J.M.C., Lourival, R., Fonseca, G.A.B., Seligmann, P.A., and Allofs, T. 2005. Pantanal: South America's Wetland Jewel. Washington, DC: Conservation International, $176 \mathrm{pp}$.

RHodin, A.G.J. 1985. Status and taxonomic relationships of South American chelid turtles.American Philosophical Society Grantee's Reports 1984:41, 291-293.

Rhodin, A.G.J., Mittermeier, R.A., AND McMorris, J.R. 1984a. Platemys macrocephala, a new species of chelid turtle from central Bolivia and the Pantanal region of Brazil. Herpetologica 40(1):38-46.

Rhodin, A.G.J., Rocha e Silva, R.D., AND Mittermeier, R.A. 1984b. Distribution of the South American chelid turtles Platemys radiolata and P. spixii. Copeia 1984(3):780-786.

Rhodin, A.G.J., MitTermeIER, R.A., AND ERnst, C.H. 1990. Acanthochelys macrocephala. Catalogue of American Amphibians and Reptiles 481:1-2.

Rueda-Almonacid, J.V., Carr, J.L., Mittermeier, R.A., RodríGuezMahecha, J.V., Mast, R.B., Vogt, R.C., Rhodin, A.G.J., De La OSSA-VelásQuez,J.,RuedA,J.N., ANDMITTERMEIER,C.G.2007.Las 
Tortugas y los Cocodrilianos de los Países Andinos del Trópico. Bogotá, Colombia: Editorial Panamericana, Formas e Impresos, Serie de Guías Tropicales de Campo No. 6, Conservación Internacional, $538 \mathrm{pp}$.

SIEBENROCK, F. 1904. Schildkröten von Brasilien. Denkschriften der Kaiserlichen Akademie der Wissenschaften, MathematischNaturwissenschaftliche Classe, Wien 76:1-28.

VinKE, T. AND VinKE, S. 2001. The turtle and tortoise fauna of the central Chaco of Paraguay. Radiata 10(3): 3-19.

Vinke, T. And Vinke, S. 2008. Die Pantanal-Plattschildkröte, Acanthochelys macrocephala, erobert den Dornbuschtrockenwald. Schildkröten im Fokus 5(1): 22-31.

Vinke, T. AND Vinke, S. In press. The Pantanal swamp turtle, Acanthochelys macrocephala. Reptilia (GB) 67: in press.

Ziegler, T., Unger, J., FeILER, A., AND Lehr, E. 2002. The first Gran Chaco expedition of the Museum für Tierkunde Dresden: records of amphibians, reptiles and mammals from the Dry Chaco of Paraguay(Amphibia,Reptilia,Mammalia).FaunistischeAbhandlungen Staatliches Museum für Tierkunde Dresden 23(5):219-238.

\section{Citation Format for this Account:}

Rhodin, A.G.J., Métrailler, S., Vinke, T., Vinke, S.,Artner, H., AND MITTERMEIER, R.A. 2009. Acanthochelys macrocephala (Rhodin, Mittermeier, and McMorris 1984) - big-headed Pantanal swamp turtle,Pantanal swamp turtle.In: Rhodin,A.G.J.,Pritchard,P.C.H., van Dijk, P.P., Saumure, R.A., Buhlmann, K.A., Iverson, J.B., and Mittermeier, R.A. (Eds.). Conservation Biology of Freshwater Turtles and Tortoises: ACompilation Project of the IUCN/SSC Tortoise and Freshwater Turtle Specialist Group. Chelonian Research Monographs No. 5, pp. 040.1-040.8, doi:10.3854/crm.5.040. macrocephala.v1.2009, http://www.iucn-tftsg.org/cbftt/. 